\title{
Composition and Quantity of Volatile Organic Compounds in Paper Mill
}

\author{
Xin Tong, Wenhao Shen* \\ State Key Laboratory of Pulp and Paper Engineering \\ South China University of Technology \\ Guangzhou, 510640, P.R. China \\ e-mail:ppwhshen@scut.edu.cn
}

\begin{abstract}
This paper analyzed volatile organic compounds (VOCs) in the ambient air of a secondary fiber paper mill. The compositions and quantities of VOCs were determined by the gas chromatography-mass spectrometry (GC-MS) method and the photo-ionisation detector (PID), respectively. The total concentrations of TVOC and the main identified kinds of substances on the four sites of paper mill were as follows: (1) waste paper sorting room: TVOC concentration was 1.18 $\mathrm{mg} \cdot \mathrm{m}^{-3}$, which exceeded the standard 0.97 multiples; the main detected pollutants were alkanes, phenols, and esters; (2) papermaking workshop: TVOC concentration was 207.75 $\mathrm{mg} \cdot \mathrm{m}^{-3}$, which exceeded the standard 345.25 multiples; the main detected pollutants were benzene series, alkanes, ethers, and phenols; (3) vacuum pump outlet: TVOC concentration was $4.78 \mathrm{mg} \cdot \mathrm{m}^{-3}$, which exceeded the standard 6.97 multiples; the main detected pollutants were benzene series and phenols; and (4) office area: TVOC concentration was $0.63 \mathrm{mg} \cdot \mathrm{m}^{-3}$, which exceeded the standard 0.05 multiples; the main detected pollutants were benzene series and phenols.
\end{abstract}

Keywords-VOCs; paper mill; GC-MS; composition

\section{INTRODUCTION}

As the world's sixth largest polluting industry, the pulp and papermaking industry emits large amounts of gaseous, liquid, and solid pollutants into the natural environment [1, 2]. According to the data from U.S. Environmental Protection Agency (EPA), the main polluting gases from paper mills include highly toxic sulfides (TRS) and volatile organic compounds (VOCs) [3]. The World Health Organization defines VOCs as the organic compounds with a lower boiling point limit of 50 to $100{ }^{\circ} \mathrm{C}$ and an upper boiling point limit of 240 to $260{ }^{\circ} \mathrm{C}$, which include alkanes (or paraffins), alkenes (or olefins), saturated and unsaturated alkyl halides, carbonyls, alcohols, aromatic and halogenated aromatic hydrocarbons [4].

When VOCs are the major emissions gaseous, the gaseous pollutants from paper industry not only cause environmental pollution, but also threaten human health [5]. Despite the possible environmental and health risks, monitoring VOCs in paper mills has not been widely concerned, and little research has been reported.

In this paper, field samplings of the ambient air were performed in four locations of a secondary fiber paper mill, solvent desorbing was conducted with carbon disulfide and dichloromethane, respectively; the compositions of VOCs were analyzed with GC-MS method, and the overall quantities of TVOC (Total volatile organic compounds) were determined by a photo-ionisation detector (PID).

\section{Materials AND Method}

A. Sampling Sites Description

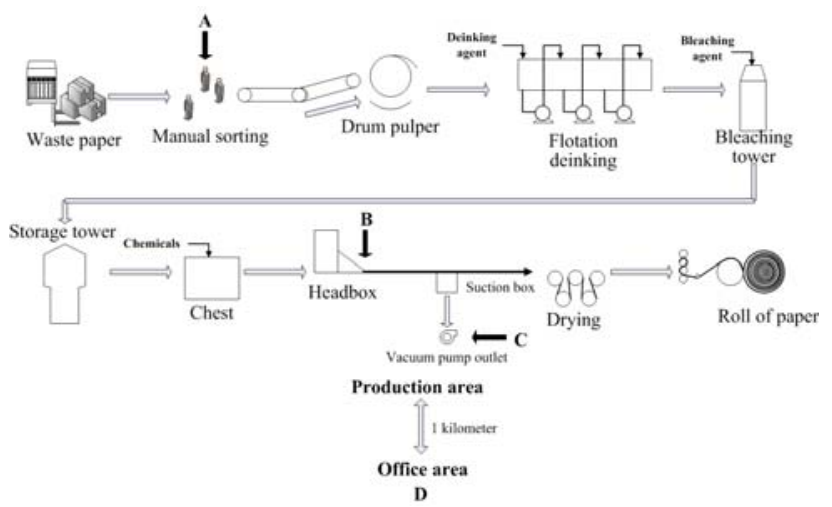

Figure 1. Flow chart of Guangzhou Paper Mill and the sampling locations: (A) waste paper sorting room, (B) papermaking workshop, (C) vacuum pump outlet, (D) office area.

The ambient air samples in the study were collected from Guangzhou Paper Mill, which is located in the southernmost part of Guangzhou (almost 50 kilometers from the downtown). Its main product is offset newsprint with annual production capacity of 557800 tons, which accounts for about $17 \%$ of the national total [6]. Using secondary fiber as raw material, $100 \%$ deinked pulp (DIP) is used to produce newsprint. The flow chart of Guangzhou Paper Mill is illustrated in Figure 1. In the study, air samples from the following four locations in the paper mill were chosen for collection and analysis: (A) waste paper sorting room, (B) papermaking workshop, (C) vacuum pump outlet, and (D) office area. Being an affiliation of paper mill, the office area is about 1 kilometer away from the production area.

\section{B. Air Sampling and Detection of TVOC}

Recording every 1 minute, the TVOC concentration was continuously measured in situ for 15 minutes by portable gas detector, whose resolution was $1 \mathrm{ppb}$, with an air pump at the speed of $220 \mathrm{~mL} \cdot \mathrm{min}^{-1}$ (First Check +5000 , Ion Science Ltd, U.K.). According to the instruction manual of First Check, 
the detector measured the levels of TVOC by PID (photoionisation detector) whose calibration and quantification were performed with isobutylene, and the data represented the levels of TVOCs in the ambient air samples.

\section{Air Sampling and Analysis of VOCs}

TABLE I. ANALYSIS CONDITIONS WITH GC-MS FOR THE COMPOSITIONS OF AIR SAMPLES IN PAPER MILL

\begin{tabular}{|c|c|c|}
\hline Parameters of GC-MS & Sample I & Sample II \\
\hline Gas carrier & Helium & Helium \\
\hline Gas flow & $0.6 \mathrm{~mL} \cdot \mathrm{min}^{-1}$ & $1 \mathrm{~mL} \cdot \mathrm{min}^{-1}$ \\
\hline Injector & Splitless, $250^{\circ} \mathrm{C}$ & Splitless, $250^{\circ} \mathrm{C}$ \\
\hline MS source temperature & $200^{\circ} \mathrm{C}$ & $230^{\circ} \mathrm{C}$ \\
\hline Oven temperature & $\begin{array}{l}30{ }^{\circ} \mathrm{C} \text { held } 1 \mathrm{~min} ; \\
10^{\circ} \mathrm{C} \cdot \mathrm{min}^{-1} \text { to } 60 \\
{ }^{\circ} \mathrm{C} ; 30^{\circ} \mathrm{C} \cdot \mathrm{min}^{-1} \text { to } \\
150{ }^{\circ} \mathrm{C} \text {, held } 15 \\
\text { min }\end{array}$ & $\begin{array}{l}40{ }^{\circ} \mathrm{C} \text { for } 2 \mathrm{~min} ; 10 \\
{ }^{\circ} \mathrm{C} \cdot \min ^{-1} \text { to } 80{ }^{\circ} \mathrm{C} \text {, } \\
\text { held for } 2 \mathrm{~min} ; 25 \\
{ }^{\circ} \mathrm{C} \cdot \min ^{-1} \text { to } 260^{\circ} \mathrm{C}, \\
\text { held } 5 \mathrm{~min}\end{array}$ \\
\hline
\end{tabular}

The air samples were collected by active sampling with a glass tube containing micro-porous activated carbon granules (Tianyue Instrument Co., China). By using an air sampling pump (TWA-300Z, Tianyue Instrument Co., China), a total of $10 \mathrm{~L}$ ambient air was collected at a height of 1.5 meters and a flow rate of $500 \mathrm{~mL} \cdot \mathrm{min}^{-1}$ for 20 minutes each time. And then, the substances in the activated carbon tubes were extracted with two kinds of solvents, carbon disulfide (I) and dichloromethane (II). The extraction steps were as follows: (1) all of the substances in the tubes were dissolved in $1 \mathrm{~mL}$ solvent and followed by the ultrasonication operation for 3 minutes; (2) the activated carbon granules were separated from the organic solvents by the natural sedimentation for 30 minutes; (3) the supernatant solutions from Step two were obtained, which were named Sample I and Sample II, separately. The determinations of the compositions of sample I and sample II were performed with a gas chromatograph coupled with a mass spectrometer (Varian-4000, Varian, Inc., USA). The DB-5MS capillary column (Agilent J\&W Scientific, USA) was used as an analytical column. The detailed analysis conditions with GC-MS for Samples I and II are shown in Table I.

\section{Results AND Discussions}

\section{A. Waste Paper Sorting Room}

As shown in Table II, the concentration of TVOC in the ambient air from Site $A$ is $1.18 \mathrm{mg} \cdot \mathrm{m}^{-3}$, which exceed the Chinese standard for indoor pollution of TVOC in civil building $\left(0.6 \mathrm{mg} \cdot \mathrm{m}^{-3}\right)$ [7]. Figure 2 (a) and Figure 2 (b) are the chromatographs of Samples I and II extracted by the carbon disulfide and dichloromethane desorption procedure respectively. As illustrated in Figure 2 (a), the amounts of those substances were relatively high compared with other sites. With the extraction of the weak polar solvent, the information in Table III shows that the following substances were detected in the site $\mathrm{A}$, and their relative quantities were: phenols $(57 \%)$, esters $(38 \%)$, alkanes $(3 \%)$, and ketones $(2 \%)$. The analyzed results of the two samples revealed that there were mainly alkane compounds, phenols, and esters with high boiling points in the waste paper sorting room of the paper mill.

\section{B. Papermaking Workshop}

The concentration of TVOC in the ambient air from Site $\mathrm{B}$ is obviously shown in Table II, which is the highest one among the all-sampling points. This analysis result is consistent with the actual process: types and amounts of functional chemical fillers, such as reinforcing agents and brighteners, are added at Site B to enhance the quality of paper; and besides that, the poor ventilation, high temperature $\left(36.2^{\circ} \mathrm{C}\right)$ and humidity $(86 \%)$ environment at Site B are the further factors, which cause the high TVOC level in that area. The total ion chromatograms and the mass spectra results of air samples from the papermaking workshop with two extraction solvents are shown in Figure 2 and Table III. The identified results demonstrated that some hazardous substances were present in the papermaking workshop, which include the benzene series, alkane compounds, phenols, ethers, etc.

\section{Vacuum Pump Outlet}

The TVOC concentration of this site is $4.78 \mathrm{mg} \cdot \mathrm{m}^{-3}$, which is much lower than that of Site B. The main reason behind is as follows: being a main location of adding large amounts of chemicals in the papermaking process, the high temperature in this area leads large amounts of VOCs in the pulp to volatilize into the ambient air of papermaking room directly; however, functioning as a dewatering device of paper machine, the strong action of negative pressure of vacuum pump collects the remaining small amount of the organic compounds in the pulp and emit from the outlet of the vacuum pump on the roof of the papermaking room. According to the process technology, the gas in the papermaking workshop is collected by an exhaust hood and discharged into the atmosphere through a vacuum pump. As illustrated in Figure 2(e), Sample I with carbon disulfide in the air of the vacuum pump outlet contained more abundant substances than other sites (Figure 2(a), (c), and, (g)). However, Sample II with dichloromethane solvent in this location had a different composition, which included phenols, esters, ketones, and olefins, and the abundance of the 6th peak in Figure 2(f) shows that phenols (88\%) were the main substances at this site.

\section{Office Area}

The TVOC concentration in the ambient air from Site D is $0.63 \mathrm{mg} \cdot \mathrm{m}^{-3}$, and its superstandard multiple is also presented in Table II. Although the TVOC level in Site D is the lowest one among four sites, it is still a little bit higher than the standard. According to the GC-MS results of Sample I as shown in Figure 2(g), only two substances were observed: benzene and methylbenzene. However, more abundant compounds were detected in Sample II by desorption with dichloromethane at this site. As shown in Figure 2(h), phenols (93\%) were the main substance. All of the interpretations of the mass spectra are listed in Table III. 
Table II. TVOC Concentrations and Their Superstandard Multiples of Air Samples on the Four Sampling Sites in Paper Mill

\begin{tabular}{|c|c|c|}
\hline Sampling sites & $\begin{array}{c}\text { TVOC concentration } \\
\left(\mathbf{m g} \cdot \mathbf{~ m}^{-3}\right)\end{array}$ & $\begin{array}{c}\text { Superstandard } \\
\text { multiples }\end{array}$ \\
\hline A & 1.18 & 0.97 \\
\hline B & 207.75 & 345.25 \\
\hline C & 4.78 & 6.97 \\
\hline D & 0.63 & 0.05 \\
\hline
\end{tabular}

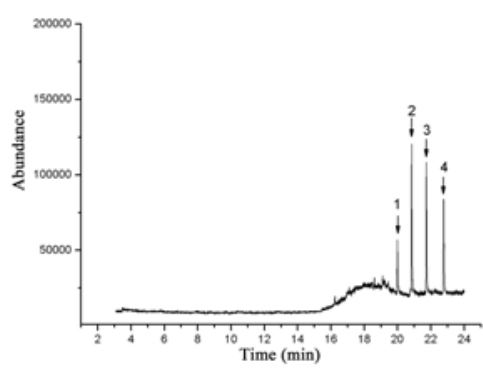

(a) Sample I in Site A

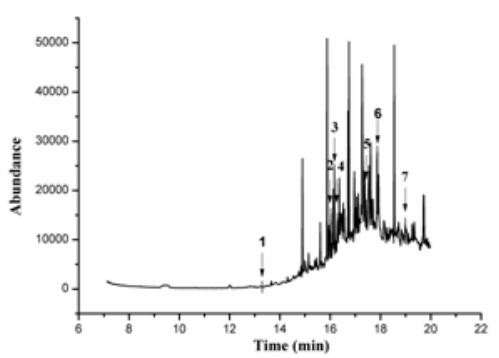

(d) Sample II in Site B

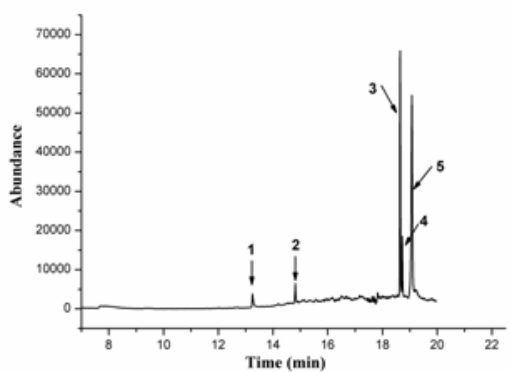

(b) Sample II in Site A

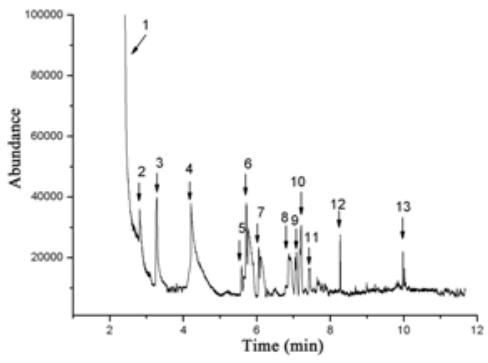

(e) Sample I in Site C

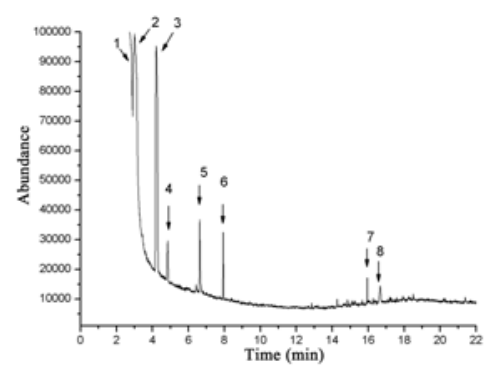

(c) Sample I in Site B

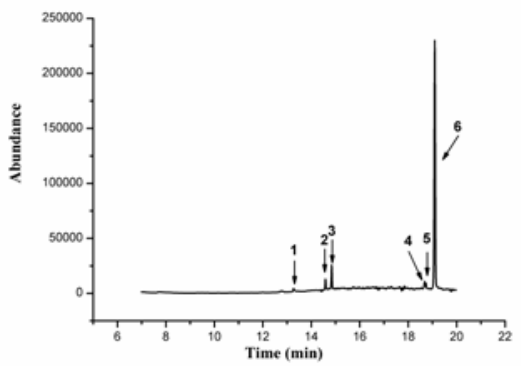

(f) Sample II in Site C

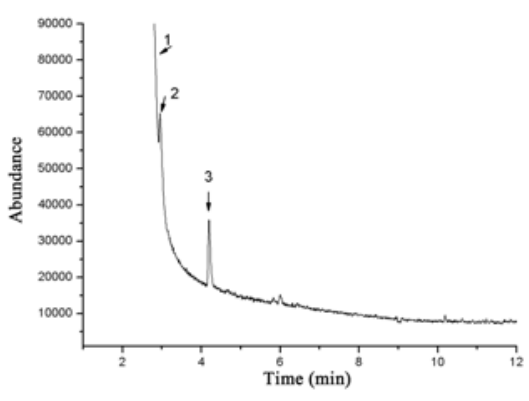

(g) Sample I in Site D

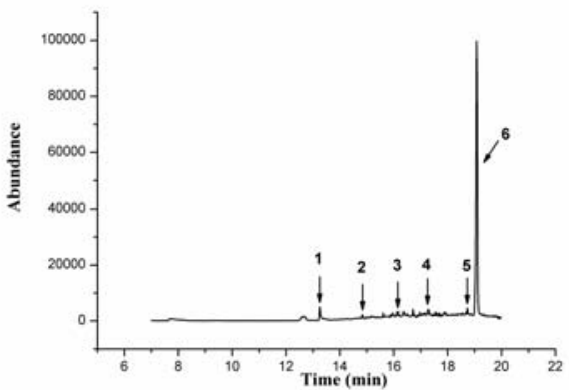

(h) Sample II in Site D

Figure 2. Total ion chromatograms of air samples from four sites in paper mill.

\section{CONClusions}

The findings in this work reveal the contents and compositions of volatile organic compounds (VOCs) in the ambient air of a secondary fiber paper mill. Considering four sites in the paper mill, PID was used firstly for the quantity analysis of TVOC; and then, the compositions of the ambient air on the four sites were determined with GC-MS method, respectively. The obtained analysis results on these four sites were as follows:

- (1) Site A, waste paper sorting room: TVOC concentration was $1.18 \mathrm{mg} \cdot \mathrm{m}^{-3}$, which exceeded the standard 0.97 multiples; the main detected pollutants were alkane compounds, phenols, and esters. 
- (2) Site B, papermaking workshop: TVOC concentration was $207.75 \mathrm{mg} \cdot \mathrm{m}^{-3}$, which exceeded the standard 345.25 multiples; the main detected pollutants were benzene series, alkanes, ethers, and phenols.

- (3) Site C, vacuum pump outlet: TVOC concentration was $4.78 \mathrm{mg} \cdot \mathrm{m}^{-3}$, which exceeded the standard 6.97 multiples; the main detected pollutants were benzene series and phenols.

- (4) Site D, office area: TVOC concentration was $0.63 \mathrm{mg} \cdot \mathrm{m}^{-3}$, which exceeded the standard 0.05 multiples; the main detected pollutants were benzene series and phenols.

Astonished by the detected results in one paper mill, the divergent thinking leads us to do further studies on the gaseous polluted situations in other paper mills.

\section{ACKNOWLEDGMENT}

The work was supported by the fund of State Key Laboratory of Pulp and Paper Engineering, South China University of Technology (No. 2015C07). Field sampling in Guangzhou Paper Mill and the help of engineers are gratefully acknowledged.

\section{REFERENCES}

[1] M. Ali, and T. R. Sreekrishnan, "Aquatic toxicity from pulp and paper mill effluents: A review," Advances in Environmental Research, vol. 5, May 2001, pp. 175-196, doi: 10.1016/S10930191(00)00055-1.

[2] R. Chandra, and M. Sankhwar, "Influence of lignin, pentachlorophenol and heavy metal on antibiotic resistance of pathogenic bacteria isolated from pulp paper mill effluent contaminated river water," Journal of Environmental Biology, vol. 32, Nov. 2011, pp. 739-745.

[3] US Environmental Protection Agency, "Transforming paper mill pollution into commercial resource," 2013. http://www.epa.gov/sciencematters/june2011/papermill.htm.

[4] B. K. Ince, Z. Cetecioglu, and O. Ince, "Pollution prevention in the pulp and paper industries," Environmental Management in Practice, E. Broniewicz (ed.), InTech, Croatia, 2011.

[5] Y. Tao, C. Y. Wu, and D. W. Mazyck, "Removal of methanol from pulp and paper mills using combined activated carbon adsorption and photocatalytic regeneration," Chemosphere, vol. 65, Sep. 2006, pp. 35-42, doi: 10.1016/j.chemosphere.2006.03.019.

[6] China Technical Association of Paper Industry, "China paper industry in 2014," China Pulp \& Paper Industry, vol. 36, 2015, pp. 28-38.

[7] GB 50325-2010, Code for indoor environmental pollution control of civil building engineering, 2010.

[8] X. Tong, Z. B. Zhang, X. Q. Chen, and W. H. Shen, "Analysis of volatile organic compounds in the ambient air of a paper mill-a case study," Bioresources, vol. 10, 2015, pp. 8487-8497, doi: 10.15376/biores. 10.4. 8487-8497.

TABLE III.

GC-MS Analytical Results of Air Samples on the Four Sampling Sites of Paper Mill [8]*

\begin{tabular}{|c|c|c|c|c|c|c|c|c|}
\hline $\begin{array}{l}\text { Sampling } \\
\text { sites }\end{array}$ & \multicolumn{4}{|c|}{ Desorption operation with Carbon disulfide (Sample I) } & \multicolumn{4}{|c|}{ Desorption operation with Dichloromethane (Sample II) } \\
\hline \multirow{4}{*}{ A } & No. & Organic pollutant & $\begin{array}{c}\text { Molecular } \\
\text { formula }\end{array}$ & $\begin{array}{c}\text { Matching } \\
\text { degree }(\%)\end{array}$ & No. & Organic pollutant & $\begin{array}{c}\text { Molecular } \\
\text { formula }\end{array}$ & $\begin{array}{c}\text { Matching } \\
\text { degree }(\%)\end{array}$ \\
\hline & 1 & Nonadecane & $\mathrm{C}_{19} \mathrm{H}_{40}$ & 95 & 1 & 2-Hydroxy-1-phenylethanone & $\mathrm{C}_{8} \mathrm{H}_{8} \mathrm{O}_{2}$ & 95 \\
\hline & 2 & Tetracosane & $\mathrm{C}_{24} \mathrm{H}_{50}$ & 90 & & & & \\
\hline & 3 & Octacosane & $\mathrm{C}_{28} \mathrm{H}_{58}$ & 85 & & & & \\
\hline \multirow{5}{*}{ B } & 1 & Carbon disulfide & $\mathrm{CS}_{2}$ & 97 & 1 & $\begin{array}{l}\text { 2-Hydroxy-1-phenylet } \\
\text { hanone }\end{array}$ & $\mathrm{C}_{8} \mathrm{H}_{8} \mathrm{O}_{2}$ & 95 \\
\hline & 2 & Benzene & $\mathrm{C}_{6} \mathrm{H}_{6}$ & 94 & 2 & Heptadecane & $\mathrm{C}_{17} \mathrm{H}_{36}$ & 82 \\
\hline & 3 & Methyl-benzene & $\mathrm{C}_{7} \mathrm{H}_{8}$ & 93 & 3 & 9-Acridone & $\mathrm{C}_{13} \mathrm{H}_{9} \mathrm{NO}$ & 81 \\
\hline & 4 & p-xylene & $\mathrm{C}_{8} \mathrm{H}_{10}$ & 88 & & & & \\
\hline & 5 & 2-Ethyltoluene & $\mathrm{C}_{9} \mathrm{H}_{12}$ & 90 & & & & \\
\hline \multirow{5}{*}{$\mathrm{C}$} & 1 & Carbon disulfide & $\mathrm{CS}_{2}$ & 98 & 1 & 2,2-Dimethylpropiophenone & $\mathrm{C}_{11} \mathrm{H}_{14} \mathrm{O}$ & 79 \\
\hline & 2 & Benzene & $\mathrm{C}_{6} \mathrm{H}_{6}$ & 95 & 2 & cis-9-Heneicosene & $\mathrm{C}_{21} \mathrm{H}_{42}$ & 79 \\
\hline & 3 & Methyl-benzene & $\mathrm{C}_{7} \mathrm{H}_{8}$ & 93 & 3 & cis-11-Tetradecenyl acetate & $\mathrm{C}_{16} \mathrm{H}_{30} \mathrm{O}_{2}$ & 77 \\
\hline & 4 & p-xylene & $\mathrm{C}_{8} \mathrm{H}_{10}$ & 80 & & & & \\
\hline & 5 & Cumene & $\mathrm{C}_{9} \mathrm{H}_{12}$ & 83 & & & & \\
\hline \multirow{3}{*}{$\mathrm{D}$} & 1 & Carbon disulfide & $\mathrm{CS}_{2}$ & 97 & 1 & 2-Hydroxy-1-phenylethanone & $\mathrm{C}_{8} \mathrm{H}_{8} \mathrm{O}_{2}$ & 96 \\
\hline & 2 & benzene & $\mathrm{C}_{6} \mathrm{H}_{6}$ & 86 & 2 & cis-9-Heneicosene & $\mathrm{C}_{21} \mathrm{H}_{42}$ & 82 \\
\hline & 3 & methylbenzene & $\mathrm{C}_{7} \mathrm{H}_{8}$ & 90 & 3 & 2,4,6-Trimethyldecane & $\mathrm{C}_{13} \mathrm{H}_{28}$ & 88 \\
\hline
\end{tabular}

* Due to the limitation of space, only those organic pollutants whose matching degrees were around $80 \%$ are listed in Table III. 